\title{
Factors Affecting Corporate Tax Avoidance Practices on the Indonesia Stock Exchange
}

\author{
Omi Pramiana*, Agus Taufik Hidayat, Dwi Ermayanti Susilo, Sugeng Suprapto, Rachyu Purbowati \\ Accounting Department \\ STIE PGRI Dewantara Jombang \\ East Java, Indonesia \\ *omi.dewantara@gmail.com, agustaufihidayat7799@gmail.com,dwi.stiedw@gmail.com, sugeng.dewantara@gmail.com, \\ rachyu.dewantara@gmail.com
}

\begin{abstract}
This study was conducted to know the factor effecting of financial reporting aggressiveness and tax avoidance. The data used are secondary data taken from the financial report of the Mining Sector companies listed on the Indonesia Stock Exchange with as many as $\mathbf{1 6 4}$ financial reports, data analysis using Partial Lease Square (PLS) with warp PLS. The results showed that executive compensation had a significant negative effect on aggressiveness in financial reporting, and gender diversification had a significant positive effect on aggressiveness in financial reporting. Executive compensation has an insignificant negative effect on tax avoidance, gender diversification has a positive and insignificant effect on tax avoidance, and financial reporting aggressiveness has a significant positive effect on tax avoidance. Financial reporting aggressiveness can be a full mediating variable between executive compensation and tax avoidance, financial reporting aggressiveness can be a partial mediating variable between gender diversification and tax avoidance.
\end{abstract}

Keywords-executive compensation, gender diversification, financial reporting aggressiveness, tax avoidance

\section{INTRODUCTION}

In the State Budget posture of 2019, tax revenue in Indonesia is recorded as contributing $82.5 \%$ of total state revenue (Ministry of Finance, 2019), it means that tax is still an important element to support state budget revenue. State revenue derived from taxes is used by the government to finance national development to achieve the prosperity of the people [1].

The high level of tax revenue in the APBN posture is not accompanied the large level of revenue realization. In 2019, the realization of tax revenues was recorded at only $86.5 \%$ of the 2019 State Budget target (Ministry of Finance, 2019). It can occur partly because of the interesting differences between the government and companies as taxpayers. Companies always try to minimize tax payments to the government because they think that taxes can reduce the company's economic capacity. Meanwhile, the government requires revenue that comes from taxes for the benefit of the country's economy [2].
The phenomenon of tax avoidance on companies in Indonesia has occurred in various sectors, one of which is the mining sector. According to the economic police researcher of Indonesian Publish What You Pay (PWYP), mining companies are companies that are indicated to have a lot of tax avoidance practice [3].

Earnings management actions are often ridden by individual interests from various parties, one of which is the executive. Executives can manage company earnings by the purpose of increasing the compensation they receive [4]. Activities to increase company profits through earning management, whether in accordance or not in accordance with applicable accounting principles, are known as financial reporting aggressiveness [5].

This study aims to determine what are the factors that influence financial reporting aggressiveness and tax avoidance.

Compensation received by executives is usually based on the company's profit [6]. Therefore, it is logical for company executives to manipulate earnings by using methods in accordance with accounting principles in order to increase profits. Jiwandono and Rahmawati [7] stated that giving compensation to executives can provide motivation to carry out earnings management so that the compensation they will receive increases. Research conducted by Jiwandono and Rahmawati [7] stated that total executive compensation, which is proxied as the amount of executive compensation and the amount of stock option compensation, has a positive effect on real earnings management. Managers will tend to do real earnings management to get greater compensation. Real earnings management actions are carried out through sales manipulation, reduction of discretionary expenses, and massive production.

$\mathrm{H}_{1}$ : There is an effect of executive compensation on Financial Reporting Aggressiveness

The existence of gender diversification in the ranks of company executives will lead to various variations in policies because women and men have different views because of the different characteristics inherent in them. The character of the 
company leader greatly influences the quality of earnings [8]. Gavious et al. [9] have conducted research to determine the effect of female company directors on earnings management in companies that have high technological sophistication. The results of this study indicate that companies that have female directors have a negative effect on earnings management.

$\mathrm{H}_{2}$ : There is an effect of gender diversification on Financial Reporting Aggressiveness

With the implementation of effective tax avoidance, it will minimize the company's tax burden that must be paid so that the level of profit obtained by the company is higher. High profits will satisfy the shareholders interests so that it is possible to increase executive compensation in the form of bonuses received. Research conducted by Armstrong et al. [10] shows that CEO incentives have a positive effect on tax avoidance. The CEO is considered to want to fulfill personal desires with tax avoidance action, because by minimizing the company's tax burden, it will increase the company's profits, which results in greater incentives given the large profits the company gets.

$\mathrm{H}_{3}$ : There is an effect of executive compensation on tax avoidance

Winasis and Yuyetta [11] stated that executives have an important role in making decisions, including taxation. Women and men will have different views because of the different traits that have been attached to them. The presence of female executives is expected to increase the variety of thoughts related to tax avoidance so that they can minimize the company's tax burden. Winasis and Yuyetta [11] has proven that gender diversity has a positive effect on tax avoidance. The greater the gender diversification in the company, the greater the opportunity level for tax avoidance.

$\mathrm{H}_{4}$ : There is an effect of gender diversification on tax avoidance

One of the company's motivations in carrying out earnings management is taxation motivations for efforts to save income tax [12]. Companies with income levels that tend to increase are predicted to do income decreasing to reduce taxable income so that companies can make savings on tax burdens. Pajriyansyah and Firmansyah [13] have proven that earnings management has a positive and significant effect on tax avoidance. Likewise in research conducted by Novitasari et al. [1] which states that earnings management has an effect on tax aggressiveness. Companies that have good business performance will try to keep their profits to a minimum so that taxes paid to the government are lower.

$\mathrm{H}_{5}$ : There is an effect of financial reporting aggressiveness on tax avoidance

Based on the background and supported by previous research, the conceptual framework in this study is as follows:

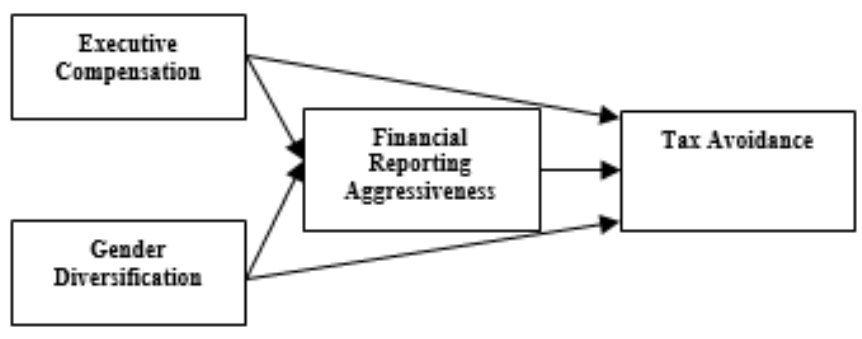

Fig. 1. Conceptual framework.

\section{METHODS}

The sample used in this study is the financial statements of 41 mining sector companies in 2015-2018, so the sample used is 164 financial reports. Data analysis using SEM-PLS method with WARP-PLS as the software. Measurement of variables as follows:

- Tax Avoidance is describing the average tax rate each unit of currency or cash flow with indicator worldwide cash income tax expense comparison to the worldwide total pre minus tax accounting income.

- Aggressiveness Financial Reporting is reflected in the company's earnings management with indicator Discretionary Accrual (DACC) (Modifikasi Model [14] (Calculating total accruals (TACC), Determine the coefficient of the Total Accrual (TACC) regression, Determining Non-Discretionary Accrual (NDACC), Determine the company's Discretionary Accrual (DACC)).

- Executive compensation is everything the executive board receives with Natural logarithm of total executive compensation (komisaris \& direksi) [4].

- Gender Diversification is distribution of board members by sex within the company with indicator The number of female executives Comparison to the total board members [15].

\section{RESULTS}

\section{A. Descriptive Statistical Analysis Results}

Based on analys, it is known that the average value of executive compensation is 23.99 , which indicates a fairly large amount of compensation received by executives in mining sector companies used as the research sample. The average value of gender diversification is 7.79 , which indicates that the percentage of women in executive's formation in mining sector companies used as the research sample is relatively small. The average earnings management value is 0.00 , which indicates that the average level of earnings management in mining sector companies used as the research sample is low. The average tax avoidance value is 0.37 , which indicates that the average level of tax avoidance in mining sector companies used as the research sample is low. 


\section{B. Model Fit Test}

1) Outer model test: Test results that the P-value of the two index shows a result below of 0.05 , which means that it meets the APC and ARS criteria. AVIF also shows an index below of 5 . These results indicate that the model is corresponding with the data so that it can continue the next test.

Based on the output results it states that the loading factor value > 0.7 (the value in parentheses and in bold) for each manifest variable of all constructs either executive compensation, gender diversification, earnings management, or tax avoidance, p-value also showed significant, that is $<0.05$. Likewise, for the AVE value (values in bold) shown in table 4.4 , with a value $>0.05$. With the output results above, it shows that the conditions for convergent validity has been met, it means that each manifest variable of all constructs is highly correlated.

Based on the output results, it shows that the root value of AVE is the value in parentheses and in bold is greater than the correlation between latent variables in the same column (above or below it). With these results, it indicates that the requirements for discriminant validity have been met, it means that the different manifest variables of the construct are not highly correlated.

Based on the output results, it shows that the value of composite reliability and Cronbach's alpha> 0.07. This means that the measuring instrument used is accurate in making measurements.

2) Inner model test: Based on the output results, the Rsquared value for the earnings management variable is 0.537 , it means that the earnings management variable is influenced by the executive compensation and gender diversification by $53.7 \%$. The output results also shows that the R-squared value for the tax avoidance variable is 0.575 , it means that the tax avoidance variable is influenced by the executive compensation, gender diversification, and earnings management by $53.7 \%$.

Based on the output results shows that the Q-square value in this research model is greater than 0 namely 0.502 and 0.602 , so it means that the research model has good predictive validity.

\section{Hypothesis Test}

1) Direct effect: Based on Path Coefiicients and P-values the direct relationship between variables is as follows

- Executive compensation has a negative and significant effect on the aggressiveness of financial reporting, indicated by a path value of -0.514 and a P-value $<0.001<0.05$ which means significant.

- Gender diversification has a positive and significant effect on the aggressiveness of financial reporting, indicated by a path value of 0.218 and a P-value of $0.011<0.05$, which means significant.
- Executive compensation has a negative and insignificant effect on tax avoidance, indicated by a path value of -0.099 and a P-value of $0.266>0.05$, which means it is not significant.

- Gender diversification has a positive and insignificant effect on tax avoidance, indicated by a path value of 0.238 and a P-value of $0.065>0.05$, which means it is not significant.

- Financial reporting aggressiveness has a positive and significant effect on tax avoidance, indicated by a path value of 0.551 and a $\mathrm{P}$-value $<0.001<0.05$ which means significant.

2) Indirect effect: Based on Indirect Effect and P-values the results of the indirect relationship are as follows:

- Executive compensation has a negative effect on tax avoidance indirectly and through earnings management of -0.301 with $p$-values of $0.006<0.05$, which means significant.

- Gender diversification has a positive effect on tax avoidance indirectly and through earnings management of 0.131 with a $\mathrm{p}$-value of $0.022<0.05$, which means significant.

\section{Mediation Effect Test}

Based on the results of the study, it shows the path value for for the direct relationship of compensation executive effect on tax avoidance of -0.65 and significant with $p$ value $<0.01$. Furthermore, when testing the indirect effect with earnings management as the mediating variable in Figure 5, it shows that the executive compensation value pathway in tax avoidance has decreased to -0.21 and becomes insignificant with a $\mathrm{p}$ value of 0.06 . With the results of mediation test effect, it shows that the mediation form of financial reporting aggressiveness on executive compensation effect on tax avoidance is full mediation.

The direct relationship of the gender diversification effect on tax avoidance is 0.55 and it is significant with a $\mathrm{p}$ value $<0.01$. Furthermore, when testing the indirect effect with earnings management as a mediating variable in Figure 7 , it shows that the value of gender diversification pathway in tax avoidance has decreased to 0.27 and remains significant with a $\mathrm{p}$ value of 0.04 . With the test results of mediation effect, it shows that the mediation form of financial reporting aggressiveness on the effect of gender diversification on tax avoidance is partial mediation.

\section{DISCUSSION}

\section{A. The Effect of Executive Compensation toward Financial Reporting Aggressiveness}

The data analysis explains that executive compensation has negative and significant effect on the aggressiveness of financial reporting, it means that the higher the executive 
compensation, the more the company does not take earnings management actions, and vice versa, the lower the executive compensation, the more the company will take earnings management actions. Executive compensation data in this study shows a fairly high tendency, and earnings management data tends to be low so that this condition can indicate that in sample companies, executives receive large compensation, which will reduce opportunistic actions, namely earnings management. One of the reasons for this can happen is that executives want to maintain their positions in company by implementing policies that avoid risk so as to prevent job changes. According to Ben Hassen [4] compensation can align the interests of stakeholders with company executives. Giving high salaries will prevent agency conflicts to prevent opportunistic behavior from executives who aim to prioritize their personal interests.

\section{B. The Effect of Gender Diversification on Financial Reporting Aggressiveness}

The data analysis explains that gender diversification has positive and significant effect on financial reporting aggressiveness, it means that the higher the gender diversity in the company's executives, the higher the earnings management actions are taken, and vice versa, the lower the gender diversity in the company's executives, the lower earnings management actions taken. Gender diversification data shows a low tendency and earnings management data also tends to be low, this shows that the low percentage of women in formation of sample company executives will reduce opportunistic actions, namely earnings management. The small number of female executives will reduce the diversity of decisions and ideas of executives in terms of earnings management so as to reduce the opportunistic actions of corporate executives through earnings management actions.

This study results are different from previous research conducted by Gavious et al. [9] which explains that a high percentage of women leaders can reduce opportunistic actions including earnings management because women are considered more ethical and tend to avoid risks. However, this study gives different results that a low percentage of women leaders can actually reduce earnings management actions.

\section{Compensation Executive Effect on Tax Avoidance}

The data analysis explains that executive compensation has negative and insignificant effect on tax avoidance, it means that the more compensation the executive receives, the more companies do not practice tax avoidance, and vice versa, the less compensation the executive receives, the more the company will practice tax avoidance, but the effect is not big. The amount of compensation received by executives in the form of salaries, bonuses, and allowances is not able to have a major effect on reducing tax avoidance measures. Therefore, if the company wants to suppress tax avoidance, it can try to implement a stock based compensation system. The results of this study are supported by research conducted by Puspita and Harto [16] which also proves that executive compensation has no significant effect on tax avoidance. The compensation system in Indonesia does not motivate executives in making corporate tax decisions.

\section{Gender Diversification Effect on Tax Avoidance}

The data analysis explains that gender diversification has positive and insignificant effect on tax avoidance, it means that the higher the gender diversity in company executives, the more companies do not practice tax avoidance, and vice versa, the less gender diversity in company executives, the more companies will practice tax avoidance, but the effect is not large. The diversity of knowledge and insights due to gender diversification in leadership formation has not been able to have a major influence on tax avoidance actions. The number of female leaders is relatively small $(7.7 \%)$ so that the behavior of female executives cannot influence the results of decisions taken, especially in tax avoidance measures. The research results are supported by previous research that has been carried out, that is research conducted by Khaoula and Mohamed [17] which explains that diversity in terms of opinions, knowledge, and experiences due to gender diversity in the company's board of directors, are less able to create tax-planning strategies, which is appropriate to minimize the company's tax burden.

\section{E. The Effect of Financial Reporting Aggressiveness on Tax Avoidance}

The data analysis explains that the financial reporting aggressiveness has positive and significant effect on tax avoidance; it means that the higher the level of corporate financial reporting aggressiveness, the higher level of corporate tax avoidance, and vice versa, the lower corporate financial reporting aggressiveness, the lower level of corporate tax avoidance. The financial reporting aggressiveness shows a low tendency and tax avoidance data also tends to be low, this shows that when company management reduces earnings management actions, tax avoidance actions are reduced. This can occur when company management wants to maintain the quality of the company's earnings to reduce unethical actions that can drop the company's prestige in public because of the low profit value when the company does tax avoidance. The results of the study are supported by previous research by Pajriyansyah and Firmansyah [13] which argues that earnings management plays an important role in corporate tax avoidance practices. Companies to carry out tax management with the aim to minimize the tax burden that must be paid will apply earnings management

\section{F. Financial Reporting Aggressiveness Is A Mediating Variable In The Relationship Between Executive Compensation And Tax Avoidance}

Based on the mediation effect test, it explains that financial reporting aggressiveness can be a full mediating variable between executive compensation and tax avoidance; it means that financial reporting aggressiveness is fully able to mediate the negative effect of executive compensation on tax avoidance. The negative path value of the executive 
compensation effect on tax avoidance, which is mediated by financial reporting aggressiveness, shows that high compensation does not have a direct effect on reducing tax avoidance practices but depends on reducing aggressiveness in financial reporting at the company.

\section{G. Financial Reporting Aggressiveness Is A Mediating Variable In The Relationship Between Gender Diversification And Tax Avoidance}

Based on the mediation effect test, it explains that financial reporting aggressiveness can be a partial mediation variable between gender diversification and tax avoidance, it means that gender diversification can have a positive effect on tax avoidance if executives carry out earnings management, but financial reporting aggressiveness is not the only way that can be done. It is because only mediates partially so that there are other factors that mediate the effect of gender diversification on tax avoidance. Company executives who have gender diversity through certain policies as intermediaries, one of which is by performing earnings management, can carry out tax avoidance.

\section{CONCLUSION}

The results of this study found that executive compensation has negative and significant effect on financial reporting aggressiveness, gender diversification has a positive and significant effect on aggressiveness of financial reporting. Executive compensation has a negative and insignificant effect on tax avoidance, gender diversification has a positive and insignificant effect on tax avoidance, and financial reporting aggressiveness has a positive and significant effect on tax avoidance. Financial reporting aggressiveness can be a full mediating variable between executive compensation and tax avoidance, financial reporting aggressiveness can be a partial mediating variable between gender diversification and tax avoidance.

\section{ACKNOWLEDGMENT}

Thanks to reviewers for the comments and suggestions given. Thank you to all those who contributed to this research.

\section{REFERENCES}

[1] S. Novitasari, V. Ratnawati, and A. Silfi, "Pengaruh Manajemen Laba, Corporate Governance dan Intensitas Modal terhadap Agresivitas Pajak Perusahaan,” J. Online Mhs. Fak. Ekon. Univ. Riau, vol. 4, no. 1, pp. 1901-1914, 2017.

[2] N. Novita, "Executives Characters, Gender and Tax Avoidance: A Study on Manufacturing Companies in Indonesia," vol. 15, pp. 92-95, 2016.

[3] A. Nuraeni, "Publish What You Pay Indonesia. Diambil kembali dari Publish What You Pay Indonesia," https://pwypindonesia.org/, p. Diakses pada 17 Mei 2020, 2015.

[4] R. Ben Hassen, "Executive Compensation and Earning Management," Int. J. Account. Financ. Report., vol. 4, no. 1, p. 84, 2014.

[5] M. margaret Frank, L.J. Lynch, and S. O. Rego, "Tax Reporting Aggressiveness and Its Relation Financial Reporting University of Virginia," Account. Rev., vol. 84, no. 2, pp. 467-496, 2009.

[6] N. Putri and W. Fadhlia, "Pergantian Ceo, Penghindaran Pajak, Kompensasi Eksekutif Dan Manajemen Laba Studi Kausalitas Pada Perusahaan Manufaktur Indonesia,” J. Ilm. Mhs. Ekon. Akunt., vol. 2, no. 3, pp. 86-99, 2017.

[7] L.Y. Jiwandono and R. Rahmawati, "Total Kompensasi Eksekutif Dan Manajemen Laba Riil (Studi Empiris pada Perusahaan Manufaktur yang Terdaftar di BEI tahun 2010-2013)," J. Akunt. dan Bisnis, vol. 15, no. 1, p. 23, 2015.

[8] D. Fatimah, "Pengaruh Board Diversity terhadap Manajemen Laba," J. Appl. Account. Tax., vol. Vol. 4, No, 2019.

[9] I. Gavious, E. Segev, and R. Yosef, "Female directors and earnings management in high-technology firms," Pacific Account. Rev., vol. 24, no. 1 , pp. 4-32, 2012.

[10] C.S. Armstrong, J.L. Blouin, A.D. Jagolinzer, and D.F. Larcker, "Corporate governance, incentives, and tax avoidance," J. Account. Econ., vol. 60, no. 1, pp. 1-17, 2015.

[11] S.E. Winasis and E. N. A. Yuyetta, "Pengaruh Gender Diversity Eksekutif Terhadap Nilai Perusahaan, Tax Avoidance Sebagai Variabel Intervening: Studi Kasus Pada Perusahaan Pertambangan Yang Terdaftar Di Bei Tahun 2012-2015,” Diponegoro J. Account., vol. 6, no. 1, pp. 311-324, 2017.

[12] William R Scott, "Financial Accounting Theory," Toronto: Pearson Prentice Hall, 2009.

[13] R.- Pajriyansyah and A.- Firmansyah, "Pengaruh Leverage, Kompensasi Rugi Fiskal Dan Manajemen Laba Terhadap Penghindaran Pajak," Keberlanjutan, vol. 2, no. 1, p. 431, 2017.

[14] J.J. Jones, "Earnings Management During Import Relief Investigations," ournal Account. Res., vol. Vol 29, No, p. p.193 - 228., 1991.

[15] O. Oyenike, E. Olayinka, and F. Emeni, "Female Directors and Tax Aggressiveness of Listed Banks in Nigeria," pp. 293-299, 2016.

[16] S.R. Puspita and P. Harto, "Pengaruh Tata Kelola Perusahaan Terhadap Penghindaran Pajak," Pengaruh Tata Kelola Perusah. Terhadap Penghindaran Pajak, vol. 3, no. 2, pp. 1077-1089, 2014.

[17] A. Khaoula and Z. Mohamed Ali, "Demographic Diversity in the Board and Corporate Tax Planning in American Firms," Bus. Manag. Strateg., vol. 3, no. 1, 2012. 